\title{
INFLUENCE OF HYDROCOLLOIDS ADDITION ON THE RHEOLOGICAL PROPERTIES OF WHEY MODEL SOLUTIONS
}

\author{
Z. HERCEG, V. HEGEDUŠIĆ and S. RIMAC
}

Faculty of Food Technology and Biotechnology,10000 Zagreb, Pierottijeva 6. Croatia

(Received: 13 January 1999; revision received: 11 October 1999; accepted: 1 December 1999)

The aim of this work was to investigate the influence of several carboxymethylcellulose hydrocolloids addition on the rheological properties of whey model systems as well as sucrose sorbitol - water solutions. Measurements were done by rotational viscosimeter, Brookfield DV-III at $20^{\circ} \mathrm{C}$.

The rheological parameters were determined by Ostwald and Reiner's power-law model.

The results of variance analysis showed that all investigated sources of variation (model solution composition, type of hydrocolloids and freezing process) had a significant influence on the rheological parameter (consistency coefficient).

Due to the interaction of hydrocolloid and whey proteins or minerals the viscosity of the model solutions prepared with ultrafiltrated whey dropped substantially.

Freezing process increased the viscosity of whey solutions, while the viscosity of solutions prepared with water did not change significantly.

Keywords: rheological properties, hydrocolloids, whey, freezing.

Hydrocolloids such as carboxymethylcellulose are important ingredients of ice creams and other frozen dairy desserts, where they have many functions: viscosity and stability increasing, control of crystallization, inhibition of recrystallization, as well as aiding aeration (DZIEZAK, 1991; GOFF et al., 1993; PILIŽOTA et al., 1996; VAFIADIS, 1997).

The type of hydrocolloids largely determines overall appearance, texture and rheological properties of food, whereby nutritional values and sensory qualities of food products are not changed (DZIEZAK, 1991; HEGEDUŠIĆ et al., 1995). Positive effects are achieved in the foods which are consumed frozen or which are preserved by freezing in order to reduce negative effects related to phase transitions (HEGEDUŠIć et al., 1991; HEGEDUŠIĆ et al., 1995). Their activity could depend on interaction between hydrocolloids as well as interaction between hydrocolloids and other components of food (ŠUBARIĆ et al., 1994). Consequently, it is important to identify optimum conditions at which each stabilizer would be the most effective for the desired product properties. 
Ultrafiltrated whey and whey proteins are used in the food and beverages industries for production of frozen desserts and ice creams for replacing certain quantities of caseinates, egg whites, carbohydrates. They are also acting as gelling agents or enhance functional properties of food (KINSELLA \& WHITEHEAD, 1989; KER \& TOLEDO, 1992; KING, 1996). The ability of proteins to form solid gels and their coagulations during heating are important physicochemical factors, which affect functional properties of food and water holding capacity (XU et al., 1992; HEGEDUŠIĆ et al., 1994; HEGEDUŠIĆ et al., 1995).

The functional role of protein as a food ingredient depends on the complex interaction of various factors, for example, heating or cooling rates, protein concentration, $\mathrm{pH}$, ionic strength and interactions with other food components, (Boye et al., 1997; BHARGAVA \& JELEN, 1995; AlizAdEHFARD \& WiLEY, 1995). Salt, glucose and sucrose increase the stability of whey proteins (BOYE et al., 1995).

The aim of this work was to investigate the influence of several carboxymethylcelullose hydrocolloids addition on the rheological properties of whey model solutions as well as sucrose - sorbitol - water solutions and determine the effect of freezing process on the viscosity of the model solutions.

\section{Materials and methods}

Investigations were carried out with seven various model systems (marked as samples 1 to 7), prepared by mixing the following ingredients (Table 1):

Sucrose, N-crystal

Sorbitol - "Merck"

Ultrafiltrated whey (10\% solid matter) - "Dukat"

Hydrocolloids - carboxymethylcellulose (CMC) - (YO-L, YO-H, YO-M) - GuliverChemie, Wiener Neudorf

Chemical composition of ultrafiltrated whey was determined using official methods. Solid matter content was determined by drying at $105{ }^{\circ} \mathrm{C}$ to the constant mass, proteins content by Kjeldahl method using Kjeltec system, lactose content according to the Luff-Schoorl's method.

Ultrafiltrated whey in solid matter contains $60 \%$ whey proteins, $39.24 \%$ lactose and $0.76 \%$ total ash.

The rheological properties of three different types of commercial CMC: YO-L (low viscosity), YO-H (low to medium viscosity), YO-M (medium to high viscosity), were investigated. $\mathrm{CMC}$ dispersions $(0.1,0.2$, and $0.4 \%$ mass fractions) were prepared by hydrating in distilled water by vigorous hand mixing at $20^{\circ} \mathrm{C}$ (sample No.1). 
Table 1

Composition of model systems

\begin{tabular}{|c|c|c|c|c|c|}
\hline \multirow[b]{2}{*}{$\begin{array}{l}\text { Model } \\
\text { systems }\end{array}$} & \multicolumn{5}{|c|}{ Compounds } \\
\hline & $\begin{array}{l}\text { Sucrose } \\
\text { (g) }\end{array}$ & $\begin{array}{l}\text { Sorbitol } \\
\text { (g) }\end{array}$ & $\begin{array}{l}\text { Ultrafiltrated } \\
\text { whey } \\
\text { (g) }\end{array}$ & $\begin{array}{l}\text { Water } \\
(\mathrm{g})\end{array}$ & $\begin{array}{l}\text { Hydrocolloid } \\
\text { (g) }\end{array}$ \\
\hline \multirow{3}{*}{1} & - & - & - & 90.0 & 0.1 \\
\hline & - & - & - & 90.0 & 0.2 \\
\hline & - & - & - & 90.0 & 0.4 \\
\hline \multirow{3}{*}{2} & - & - & 99.9 & - & 0.1 \\
\hline & - & - & 99.8 & - & 0.2 \\
\hline & - & - & 99.6 & - & 0.4 \\
\hline \multirow{3}{*}{3} & 4.95 & - & 49.95 & 45.0 & 0.1 \\
\hline & 4.9 & - & 49.90 & 45.0 & 0.2 \\
\hline & 4.8 & - & 49.80 & 45.0 & 0.4 \\
\hline \multirow{3}{*}{4} & - & 4.95 & 49.95 & 45.0 & 0.1 \\
\hline & - & 4.90 & 49.9 & 45.0 & 0.2 \\
\hline & - & 4.80 & 49.8 & 45.0 & 0.4 \\
\hline \multirow{3}{*}{5} & 9.9 & - & - & 90.0 & 0.1 \\
\hline & 9.8 & - & - & 90.0 & 0.2 \\
\hline & 9.6 & - & - & 90.0 & 0.4 \\
\hline \multirow{3}{*}{6} & - & 9.9 & - & 90.0 & 0.1 \\
\hline & - & 9.8 & - & 90.0 & 0.2 \\
\hline & - & 9.6 & - & 90.0 & 0.4 \\
\hline \multirow{3}{*}{7} & 4.95 & 4.95 & - & 90.0 & 0.1 \\
\hline & 4.90 & 4.90 & - & 90.0 & 0.2 \\
\hline & 4.80 & 4.80 & - & 90.0 & 0.4 \\
\hline
\end{tabular}

The purpose of model solutions of sucrose (sample No. 5), sorbitol (sample No. 6) and sucrose + sorbitol (sample No. 7) preparation was to investigate the influence of carbohydrates-hydrocolloids interactions on the rheological properties of these model systems. The samples No. 2 as well as No. 3 and No. 4 were prepared with the purpose to determine the possible interactions among proteins, minerals, hydrocolloids and carbohydrates (Table 1). 
All measurements were made five times and as a result the arithmetic mean value was used.

Rheological properties were determined using a rotational viscosimeter, Brookfield DV-III, with concentric cylinders, type MV-I, where the radius of the outer cylinder is $21 \mathrm{~mm}$, and that of the inner cylinder is $20.04 \mathrm{~mm}$. The height of the inner cylinder is $60 \mathrm{~mm}$. Shear stress against the increasing shear rates from the lowest value, $3.9 \mathrm{~s}^{-1}$ to $317 \mathrm{~s}^{-1}$ (rising measurements) as well as from $317 \mathrm{~s}^{-1}$ to the lowest shear rate values were measured. All measurements were carried out in an interval of $2 \mathrm{~min}$. Shear stress and shear rate values (rising measurements) were recalculated in flow index, and consistency coefficient value was calculated after Ostwald and Reiner's power-law model, using Brookfield's computer program.

The Ostwald and Reiner's power-law equation:

$$
\tau=k \bar{\gamma}^{n}
$$

where:

$\tau$ : shear stress $(\mathrm{Pa})$

$\bar{\gamma}$ : shear rate $(1 / \mathrm{s})$

$n$ : flow index

$k$ : consistency coefficient $\left(\mathrm{Pa} \mathrm{s}^{n}\right)$

Suitability of Ostwald and Reiner's model for data analyzing was determined after regression analysis according to the least square method.

Apparent viscosity at $60 \mathrm{~s}^{-1}$ was calculated, using Newtonian law, as a ratio between shear stress (measured value from flow curve) and the corresponding shear rate.

$$
\tau=\mu \bar{\gamma}
$$

where:

$\tau$ : shear stress $(\mathrm{Pa})$

$\bar{\gamma}$ : shear rate $(1 / \mathrm{s})$

$\mu$ : apparent viscosity (Pa s)

All measurements were made at $20^{\circ} \mathrm{C}$, after preparation and freezing $\left(-20^{\circ} \mathrm{C}\right)$ in a cabinet freezer. All frozen solutions were kept for $24 \mathrm{~h}$. After thawing and heating to $20{ }^{\circ} \mathrm{C}$ the measurements of rheological properties were performed.

Variance analysis was used for the determination of the influence of variation sources (model solution composition, kind of hydrocolloids and freezing process) on the rheological parameter (consistency coefficient). 


\section{Results}

The results of the rheological properties measurement are presented in Tables 2-7 and Figs 1-6.

It was observed that mass fraction of hydrocolloids, type of hydrocolloid as well as model solution composition had a significant influence on the type of fluidity.

The results of the rheological parameters determination showed that most of investigated solutions are non-Newtonian.

All model solutions prepared with hydrocolloids YO-H and YO-M had nonNewtonian (pseudoplastic) type fluidity.

Table 2

Rheological characteristics of model systems with hydrocolloid YO-L addition before freezing

\begin{tabular}{|c|c|c|c|c|c|c|}
\hline & $\begin{array}{c}\text { Model } \\
\text { solutions }\end{array}$ & $\begin{array}{c}\text { YO-L } \\
(\%)\end{array}$ & $\begin{array}{c}\text { Apparent } \\
\text { viscosity, } \mu \\
\text { (Pa s) }\end{array}$ & $\begin{array}{l}\text { Flow } \\
\text { index } \\
n\end{array}$ & $\begin{array}{l}\text { Consistency } \\
\text { coefficient, k } \\
\qquad\left(\mathrm{Pa} \mathrm{s}^{\mathrm{n}}\right)\end{array}$ & $\begin{array}{c}\text { Regression } \\
\text { coefficient } \\
\mathrm{r}^{2}\end{array}$ \\
\hline \multirow{3}{*}{1} & Water & 0.1 & 3.700 & 0.917 & 0.005 & 0.996 \\
\hline & solution of & 0.2 & 5.900 & 0.956 & 0.007 & 0.997 \\
\hline & hydrocolloid & 0.4 & 9.950 & 0.962 & 0.012 & 0.997 \\
\hline \multirow{3}{*}{2} & & 0.1 & 3.350 & 0.998 & 0.003 & 0.998 \\
\hline & Ultrafiltrated & 0.2 & 3.300 & 0.951 & 0.004 & 0.997 \\
\hline & whey & 0.4 & 9.250 & 0.993 & 0.009 & 0.995 \\
\hline \multirow{3}{*}{3} & Ultrafiltrated & 0.1 & 2.700 & 0.900 & 0.004 & 0.998 \\
\hline & whey + & 0.2 & 3.600 & 0.994 & 0.005 & 0.994 \\
\hline & sucrose & 0.4 & 5.800 & 0.977 & 0.004 & 0.994 \\
\hline \multirow{3}{*}{4} & Ultrafiltrated & 0.1 & 3.150 & 0.906 & 0.004 & 0.997 \\
\hline & whey + & 0.2 & 3.550 & 0.954 & 0.005 & 0.996 \\
\hline & sorbitol & 0.4 & 7.300 & 0.977 & 0.006 & 0.995 \\
\hline \multirow{3}{*}{5} & & 0.1 & 4.700 & 1.012 & 0.003 & 0.990 \\
\hline & Sucrose & 0.2 & 5.850 & 0.933 & 0.009 & 0.996 \\
\hline & & 0.4 & 10.200 & 0.935 & 0.014 & 0.995 \\
\hline \multirow{3}{*}{6} & & 0.1 & 5.400 & 1.011 & 0.005 & 0.998 \\
\hline & Sorbitol & 0.2 & 7.300 & 0.951 & 0.009 & 0.999 \\
\hline & & 0.4 & 12.500 & 0.988 & 0.013 & 0.995 \\
\hline \multirow{3}{*}{7} & Sucrose & 0.1 & 5.250 & 1.006 & 0.005 & 0.996 \\
\hline & + & 0.2 & 7.150 & 0.980 & 0.008 & 0.999 \\
\hline & sorbitol & 0.4 & 11.300 & 0.986 & 0.013 & 0.990 \\
\hline
\end{tabular}


Amount of hydrocolloids significantly influence the type of fluidity. Model solutions (sucrose, sorbitol and sucrose + sorbitol) with addition of $0.1 \%$ hydrocolloid YO-L showed characteristics of a Newtonian system. Model solutions prepared with increased amount of hydrocolloid YO-L (0.2 and $0.4 \%)$ had pseudoplastic (nonNewtonian) type of fluidity (Table 2).

The fact, that there is a significant effect (greater viscosity and stability of the emulsion, inhibiting recrystallization, etc.) when using $\mathrm{CMC}$, is very important for the development of various types of foods, in particular of frozen desserts and ice-cream. With these products it is necessary to monitor not only the effect on the viscosity of the product but also the interaction of CMC with other components present in food. Here, there are many intermolecular connections involving ion pairs creating Van der Waals reactions, which can to a large extent impinge on achieving certain characteristics of foods.

Among the many factors known to affect the rheological characteristics of matter, solid matter and its composition have the most important role (HEGEDUŠIĆ, 1992; HEGEDUŠIĆ et al., 1995). The effect of solid matter was eliminated by preparing model solutions with exactly the same solid matter (except water solution of hydrocolloids $0.4 \%$ solid matter). The purpose of preparing water solution of hydrocolloids was to observe the interaction of the ingredients in the solution with hydrocolloids and to monitor the effect on the rheological characteristics of the model solution.

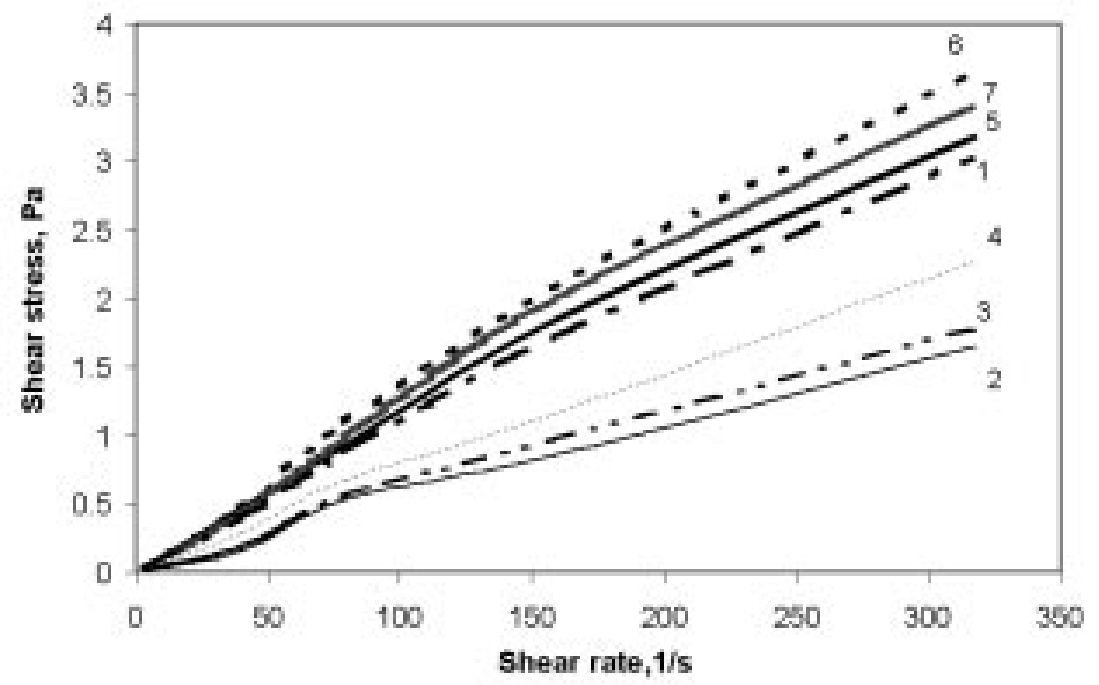

Fig. 1. Shear stress and shear rate relationship of model solutions with addition of hydrocolloids YO-L $(0.4 \%)$ before freezing. 1: water solutions of hydrocolloid; 2: ultrafiltrated whey solution; 3 : ultrafiltrated whey - sucrose solution; 4: ultrafiltrated whey - sorbitol solution; 5: sucrose; 6: sorbitol; 7: sucrose - sorbitol 
From the acquired results illustrated on the Figs. 1-3, it could be seen that the effect of the composition of solid matter is more important than the amount of solid matter, due to the fact that water solution of hydrocolloid - all involving hydrocolloids ( $0.4 \%$ solid matter) have a higher viscosity than those model solutions prepared with ultrafitrated whey $(10 \%$ solid matter) but lower than model solutions prepared with sucrose or sorbitol or a combination of sucrose-sorbitol (10\% solid matter).

In order to explain this kind of behavior of model solutions, it is needed to know that whey proteins are typical, compact globular proteins with relatively comparable distribution of nonpolar, polar and charged and uncharged remains of aminoacid. Intramolecular wrinkled structure of those proteins is a result of disulfid bonds between cistein remains (S-S), which are mostly situated inside of proteins (hydrophobic part of proteins) while outer side of proteins is made of hydrophilic remains of amino acids (TRATNIK, 1998).

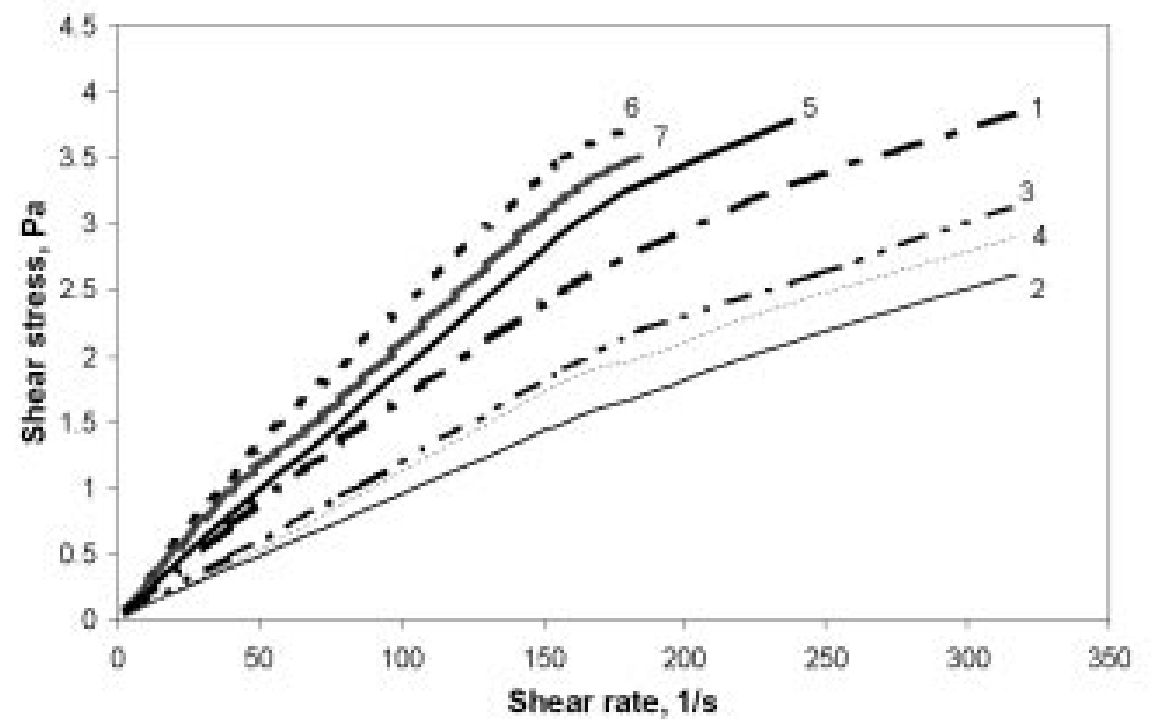

Fig. 2. Shear stress and shear rate relationship of model solutions with addition of hydrocolloids YO-H $(0.4 \%)$ before freezing. 1: water solutions of hydrocolloid; 2: ultrafiltrated whey solution; 3 : ultrafiltrated whey - sucrose solution; 4: ultrafiltrated whey - sorbitol solution; 5: sucrose, 6: sorbitol, 7: sucrose - sorbitol 
This type of behavior of model solutions with ultrafiltrated whey can be explained through the interaction of positive, active groups of proteins (hydrophilic part) and negative, active groups of hydrocolloids which in effect lowers the viscosity of the model solution since the number of groups of active hydrocolloids that can take on water has been lowered. However, during such an investigation it is necessary to take into consideration the presence of large quantities of minerals in ultrafiltrated whey as well as polyanionic hydrocolloid (CMC) characteristics which take on these minerals. This kind of interaction can lead to the homogenization of the entire system, in this case, the contact of ion pairs has a negative effect on the rheological characteristics of the model solutions.

Model solutions (ultrafiltrated whey + sucrose, ultrafiltrated whey + sorbitol) which were prepared to investigate the influence of combinations containing carbohydrates and whey proteins, as was the case with all the solutions, had a higher viscosity than model solutions prepared solely with ultrafitrated whey but a lower level of viscosity than water solution of hydrocolloids $-0.4 \%$ solid matter (Tables $2,4,6$ ). Model solutions prepared with carbohydrates clearly had the highest level of viscosity since there was no interaction between proteins and hydrocolloids (Figs 1, 2, 3).

Table 3

Rheological characteristics of model systems with $0.4 \%$ hydrocolloid YO-L after freezing

\begin{tabular}{|c|c|c|c|c|c|}
\hline & $\begin{array}{l}\text { Model } \\
\text { systems }\end{array}$ & $\begin{array}{c}\text { Apparent } \\
\text { viscosity, } \mu \\
\text { (Pa s) }\end{array}$ & $\begin{array}{c}\text { Flow } \\
\text { index } \\
n\end{array}$ & $\begin{array}{l}\text { Consistency } \\
\text { coefficient, } \mathrm{k} \\
\quad\left(\operatorname{Pa~s}^{\mathrm{n}}\right)\end{array}$ & $\begin{array}{c}\text { Regression } \\
\text { coefficient } \\
r^{2}\end{array}$ \\
\hline 1 & $\begin{array}{l}\text { Water solution of } \\
\text { hydrocolloid }\end{array}$ & 10.400 & 0.967 & 0.013 & 0.991 \\
\hline 2 & $\begin{array}{l}\text { Ultrafiltrated } \\
\text { whey }\end{array}$ & 9.980 & 0.957 & 0.010 & 0.989 \\
\hline 3 & $\begin{array}{l}\text { Ultrafiltrated } \\
\text { whey + sucrose }\end{array}$ & 10.100 & 0.973 & 0.011 & 0.996 \\
\hline 4 & $\begin{array}{l}\text { Ultrafiltrated } \\
\text { whey + sorbitol }\end{array}$ & 10.800 & 0.932 & 0.014 & 0.969 \\
\hline 5 & Sucrose & 10.800 & 0.911 & 0.016 & 0.979 \\
\hline 6 & Sorbitol & 10.600 & 0.921 & 0.016 & 0.995 \\
\hline 7 & $\begin{array}{l}\text { Sucrose + } \\
\text { sorbitol }\end{array}$ & 11.900 & 0.903 & 0.066 & 0.933 \\
\hline
\end{tabular}


However, after the freezing process had been completed there was a substantial increase in the coefficient consistency of the model solutions prepared with ultrafiltrated whey (approximately 60\%) while the coefficient consistency of water solution of hydrocolloids or model solutions prepared with carbohydrates did not change much (Tables 3, 5, 7) (Figs 4, 5, 6). This type of behavior involving solutions after they have undergone the freezing process can be explained through the changes that occur in the structure of the whey proteins while they are being frozen, which ultimately disconnects the established link between whey proteins and hydrocolloids, making them more efficient and thus allowing them to connect to larger quantities of water.

Table 4

Rheological characteristics of model systems with hydrocolloid YO-H addition before freezing

\begin{tabular}{|c|c|c|c|c|c|c|}
\hline & $\begin{array}{c}\text { Model } \\
\text { solutions }\end{array}$ & $\begin{array}{l}\text { YO-H } \\
(\%)\end{array}$ & $\begin{array}{c}\text { Apparent } \\
\text { viscosity, } \mu \\
\text { (Pa s) }\end{array}$ & $\begin{array}{c}\text { Flow } \\
\text { index } \\
n\end{array}$ & $\begin{array}{l}\text { Consistency } \\
\text { coefficient, k } \\
\quad\left(\mathrm{Pa} \mathrm{s}^{\mathrm{n}}\right)\end{array}$ & $\begin{array}{c}\text { Regression } \\
\text { coefficient } \\
r^{2}\end{array}$ \\
\hline \multirow{3}{*}{1} & \multirow{3}{*}{$\begin{array}{l}\text { Water } \\
\text { solution of } \\
\text { hydrocolloid }\end{array}$} & 0.1 & 6.100 & 0.846 & 0.014 & 0.997 \\
\hline & & 0.2 & 9.900 & 0.848 & 0.021 & 0.994 \\
\hline & & 0.4 & 14.800 & 0.852 & 0.036 & 0.996 \\
\hline \multirow{3}{*}{2} & \multirow{3}{*}{$\begin{array}{l}\text { Ultrafiltrated } \\
\text { whey }\end{array}$} & 0.1 & 2.550 & 0.963 & 0.004 & 0.996 \\
\hline & & 0.2 & 4.200 & 0.922 & 0.005 & 0.995 \\
\hline & & 0.4 & 9.300 & 0.915 & 0.012 & 0.999 \\
\hline \multirow{3}{*}{3} & \multirow{3}{*}{$\begin{array}{l}\text { Ultrafiltrated } \\
\text { whey }+ \\
\text { sucrose }\end{array}$} & 0.1 & 3.350 & 0.903 & 0.005 & 0.996 \\
\hline & & 0.2 & 4.750 & 0.960 & 0.007 & 0.997 \\
\hline & & 0.4 & 11.800 & 0.923 & 0.014 & 0.996 \\
\hline \multirow{3}{*}{4} & \multirow{3}{*}{$\begin{array}{l}\text { Ultrafiltrated } \\
\text { whey }+ \\
\text { sorbitol }\end{array}$} & 0.1 & 3.250 & 0.988 & 0.005 & 0.996 \\
\hline & & 0.2 & 5.000 & 0.938 & 0.008 & 0.998 \\
\hline & & 0.4 & 11.800 & 0.921 & 0.014 & 0.991 \\
\hline \multirow{3}{*}{5} & \multirow{3}{*}{ Sucrose } & 0.1 & 6.900 & 0.868 & 0.012 & 0.997 \\
\hline & & 0.2 & 10.200 & 0.867 & 0.015 & 0.997 \\
\hline & & 0.4 & 19.800 & 0.866 & 0.033 & 0.998 \\
\hline \multirow{3}{*}{6} & \multirow{3}{*}{ Sorbitol } & 0.1 & 7.100 & 0.908 & 0.012 & 0.992 \\
\hline & & 0.2 & 12.000 & 0.867 & 0.015 & 0.998 \\
\hline & & 0.4 & 23.000 & 0.819 & 0.033 & 0.995 \\
\hline \multirow{3}{*}{7} & Sucrose & 0.1 & 8.500 & 0.915 & 0.012 & 0.990 \\
\hline & + & 0.2 & 12.000 & 0.904 & 0.017 & 0.997 \\
\hline & sorbitol & 0.4 & 21.100 & 0.846 & 0.042 & 0.996 \\
\hline
\end{tabular}


Table 5

Rheological characteristics of model systems with $0.4 \%$ hydrocolloid YO-H after freezing

\begin{tabular}{|c|c|c|c|c|c|}
\hline & $\begin{array}{c}\text { Model } \\
\text { systems }\end{array}$ & $\begin{array}{c}\text { Apparent } \\
\text { viscosity, } \mu \\
\text { (Pa s) }\end{array}$ & $\begin{array}{c}\text { Flow } \\
\text { index } \\
n\end{array}$ & $\begin{array}{l}\text { Consistency } \\
\text { coefficient, k } \\
\left(\mathrm{Pa} \mathrm{s}^{\mathrm{n}}\right)\end{array}$ & $\begin{array}{c}\text { Regression } \\
\text { coefficient } \\
r^{2}\end{array}$ \\
\hline 1 & $\begin{array}{l}\text { Water solution of } \\
\text { hydrocolloid }\end{array}$ & 15.000 & 0.848 & 0.037 & 0.992 \\
\hline 2 & $\begin{array}{l}\text { Ultrafiltrated } \\
\text { whey }\end{array}$ & 13.200 & 0.905 & 0.021 & 0.994 \\
\hline 3 & $\begin{array}{l}\text { Ultrafiltrated } \\
\text { whey + sucrose }\end{array}$ & 17.200 & 0.877 & 0.029 & 0.994 \\
\hline 4 & $\begin{array}{l}\text { Ultrafiltrated } \\
\text { whey + sorbitol }\end{array}$ & 18.800 & 0.904 & 0.031 & 0.976 \\
\hline 5 & Sucrose & 21.600 & 0.835 & 0.045 & 0.998 \\
\hline 6 & Sorbitol & 19.400 & 0.841 & 0.040 & 0.994 \\
\hline 7 & $\begin{array}{l}\text { Sucrose }+ \\
\text { sorbitol }\end{array}$ & 23.200 & 0.832 & 0.049 & 0.970 \\
\hline
\end{tabular}

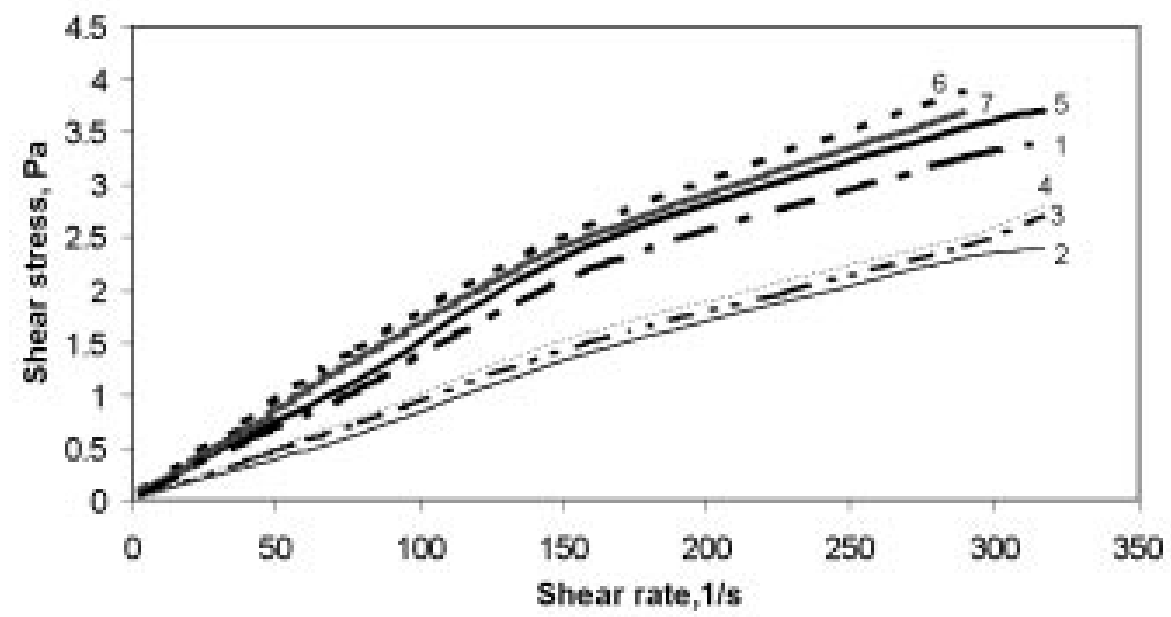

Fig. 3. Shear stress and shear rate relationship of model solutions with addition of hydrocolloids YO-M $(0.4 \%)$ before freezing. 1: water solutions of hydrocolloid; 2 : ultrafiltrated whey solution; 3 : ultrafiltrated whey - sucrose solution; 4: ultrafiltrated whey - sorbitol solution; 5: sucrose; 6: sorbitol; 7: sucrose - sorbitol 
Table 6

Rheological characteristics of model systems with hydrocolloid YO-M addition before freezing

\begin{tabular}{|c|c|c|c|c|c|c|}
\hline & $\begin{array}{c}\text { Model } \\
\text { solutions }\end{array}$ & $\begin{array}{c}\text { YO-M } \\
(\%)\end{array}$ & $\begin{array}{c}\text { Apparent } \\
\text { viscosity, } \mu \\
\text { (Pa s) }\end{array}$ & $\begin{array}{l}\text { Flow } \\
\text { index } \\
n\end{array}$ & $\begin{array}{l}\text { Consistency } \\
\text { coefficient, k } \\
\left(\mathrm{Pa} \mathrm{s}^{\mathrm{n}}\right)\end{array}$ & $\begin{array}{c}\text { Regression } \\
\text { coefficient } \\
r^{2}\end{array}$ \\
\hline \multirow{3}{*}{1} & Water & 0.1 & 5.200 & 0.870 & 0.009 & 0.996 \\
\hline & solution of & 0.2 & 7.700 & 0.876 & 0.012 & 0.997 \\
\hline & hydrocolloid & 0.4 & 14.700 & 0.884 & 0.020 & 0.998 \\
\hline \multirow{3}{*}{2} & \multirow{3}{*}{$\begin{array}{l}\text { Ultrafiltrated } \\
\text { whey }\end{array}$} & 0.1 & 2.900 & 0.850 & 0.003 & 0.995 \\
\hline & & 0.2 & 3.550 & 0.891 & 0.006 & 0.996 \\
\hline & & 0.4 & 7.900 & 0.965 & 0.009 & 0.999 \\
\hline \multirow{3}{*}{3} & \multirow{3}{*}{$\begin{array}{l}\text { Ultrafiltrated } \\
\text { whey }+ \\
\text { sucrose }\end{array}$} & 0.1 & 2.800 & 0.950 & 0.003 & 0.996 \\
\hline & & 0.2 & 3.500 & 0.922 & 0.009 & 0.993 \\
\hline & & 0.4 & 8.000 & 0.958 & 0.012 & 0.999 \\
\hline \multirow{3}{*}{4} & \multirow{3}{*}{$\begin{array}{l}\text { Ultrafiltrated } \\
\text { whey }+ \\
\text { sorbitol }\end{array}$} & 0.1 & 3.050 & 0.960 & 0.003 & 0.999 \\
\hline & & 0.2 & 3.950 & 0.941 & 0.004 & 0.998 \\
\hline & & 0.4 & 8.200 & 0.925 & 0.011 & 0.997 \\
\hline \multirow{3}{*}{5} & \multirow{3}{*}{ Sucrose } & 0.1 & 4.800 & 0.880 & 0.008 & 0.999 \\
\hline & & 0.2 & 7.350 & 0.879 & 0.013 & 0.995 \\
\hline & & 0.4 & 14.600 & 0.877 & 0.025 & 0.996 \\
\hline \multirow{3}{*}{6} & \multirow{3}{*}{ Sorbitol } & 0.1 & 5.750 & 0.900 & 0.008 & 0.994 \\
\hline & & 0.2 & 8.600 & 0.903 & 0.013 & 0.993 \\
\hline & & 0.4 & 16.100 & 0.891 & 0.021 & 0.992 \\
\hline \multirow{3}{*}{7} & Sucrose & 0.1 & 5.900 & 0.870 & 0.010 & 0.990 \\
\hline & + & 0.2 & 8.500 & 0.884 & 0.015 & 0.993 \\
\hline & sorbitol & 0.4 & 16.300 & 0.869 & 0.028 & 0.998 \\
\hline
\end{tabular}


Table 7

Rheological characteristics of model systems with $0.4 \%$ hydrocolloid YO-M after freezing

\begin{tabular}{|c|c|c|c|c|c|}
\hline & $\begin{array}{c}\text { Model } \\
\text { systems }\end{array}$ & $\begin{array}{c}\text { Apparent } \\
\text { viscosity, } \mu \\
\text { (Pa s) }\end{array}$ & $\begin{array}{c}\text { Flow } \\
\text { index } \\
n\end{array}$ & $\begin{array}{c}\text { Consistency } \\
\text { coefficient, k } \\
\left(\mathrm{Pa} \mathrm{s}^{\mathrm{n}}\right)\end{array}$ & $\begin{array}{c}\text { Regression } \\
\text { coefficient } \\
r^{2}\end{array}$ \\
\hline 1 & $\begin{array}{l}\text { Water solution of } \\
\text { hydrocolloid }\end{array}$ & 14.800 & 0.876 & 0.025 & 0.998 \\
\hline 2 & $\begin{array}{l}\text { Ultrafiltrated } \\
\text { whey }\end{array}$ & 12.000 & 0.901 & 0.018 & 0.991 \\
\hline 3 & $\begin{array}{l}\text { Ultrafiltrated } \\
\text { whey }+ \text { sucrose }\end{array}$ & 13.200 & 0.893 & 0.021 & 0.998 \\
\hline 4 & $\begin{array}{l}\text { Ultrafiltrated } \\
\text { whey }+ \text { sorbitol }\end{array}$ & 12.600 & 0.931 & 0.023 & 0.998 \\
\hline 5 & Sucrose & 15.200 & 0.832 & 0.032 & 0.999 \\
\hline 6 & Sorbitol & 16.300 & 0.860 & 0.030 & 0.999 \\
\hline 7 & $\begin{array}{l}\text { Sucrose }+ \\
\text { sorbitol }\end{array}$ & 16.100 & 0.832 & 0.034 & 0.998 \\
\hline
\end{tabular}

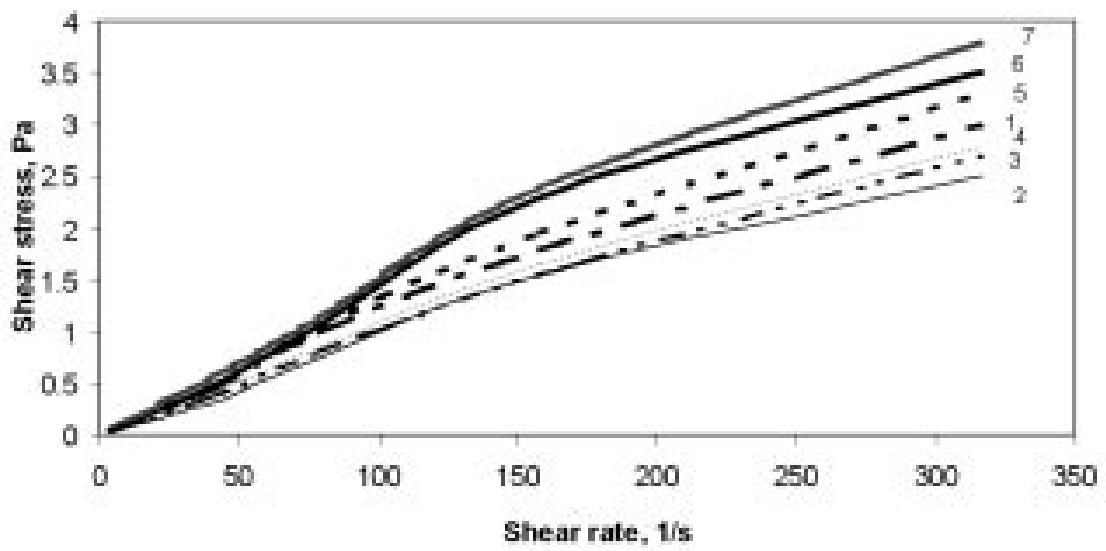

Fig. 4. Shear stress and shear rate relationship of model solutions with addition of hydrocolloids YO-L (0.4\%) after freezing. 1: water solution of hydrocolloid; 2 : ultrafiltrated whey solution; 3 : ultrafiltrated whey - sucrose solution; 4: ultrafiltrated whey - sorbitol solution; 5: sucrose; 6: sorbitol; 7: sucrose - sorbitol 


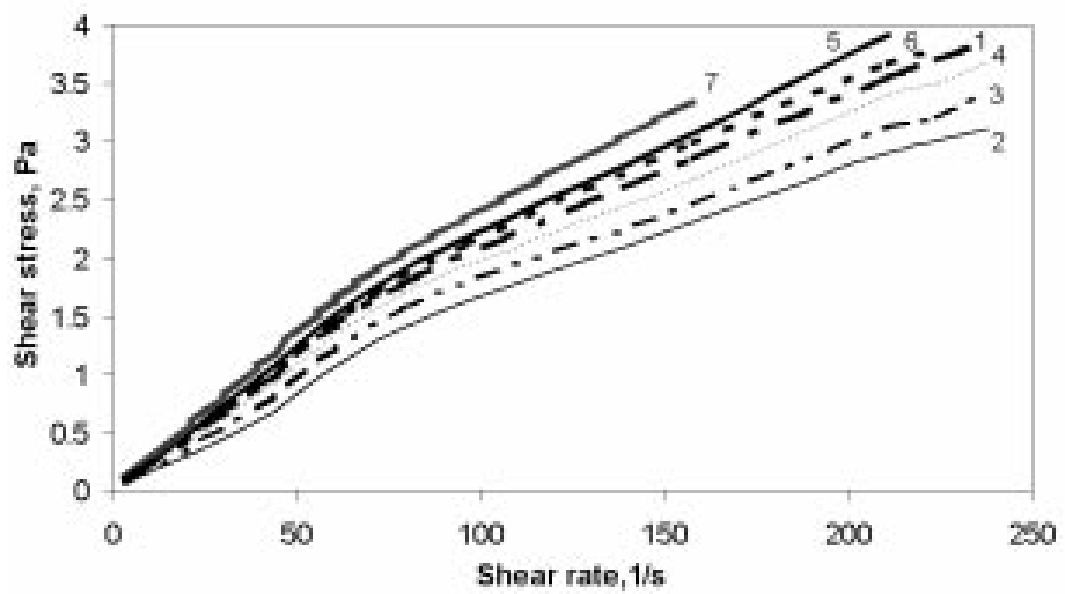

Fig. 5. Shear stress and shear rate relationship of model solutions with addition of hydrocolloids YO-H ( $0.4 \%)$ after freezing. 1: water solution of hydrocolloid; 2 : ultrafiltrated whey solution; 3 : ultrafiltrated whey - sucrose solution; 4: ultrafiltrated whey - sorbitol solution; 5: sucrose; 6: sorbitol; 7: sucrose - sorbitol

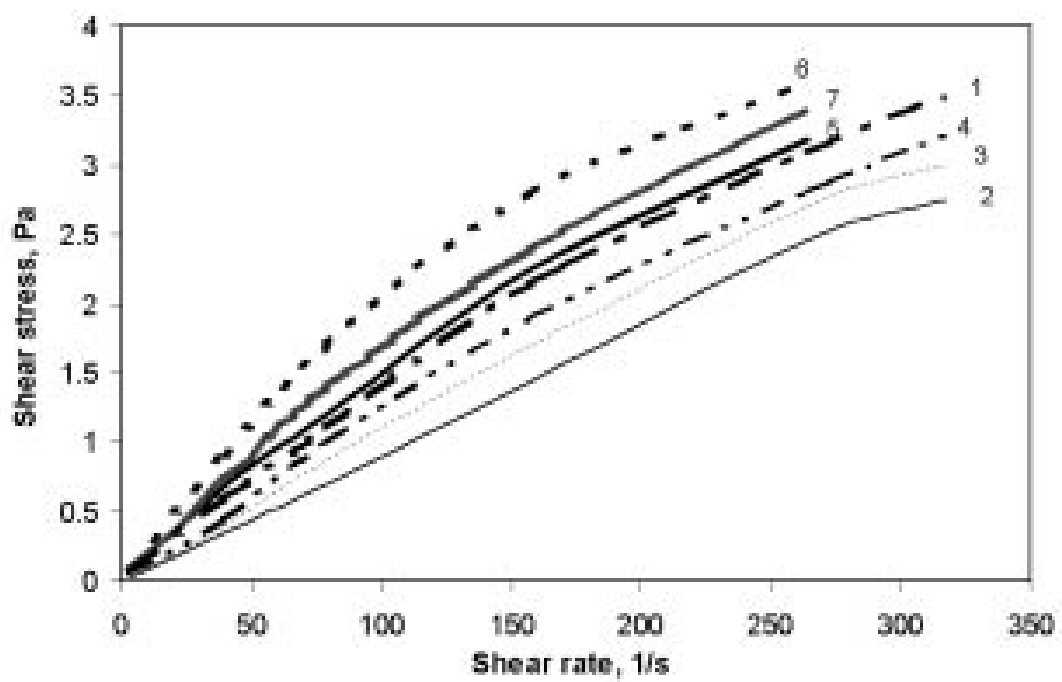

Fig. 6. Shear stress and shear rate relationship of model solutions with addition of hydrocolloids YO-M $(0.4 \%)$ after freezing. 1 : water solution of hydrocolloid; 2 : ultrafiltrated whey solution; 3 : ultrafiltrated whey - sucrose solution; 4: ultrafiltrated whey - sorbitol solution; 5: sucrose; 6: sorbitol; 7: sucrose - sorbitol 
Table 8

Analysis of variance for consistency coefficient of hydrocolloids (0.4\%), freezing process and the examined model systems

\begin{tabular}{lcccr}
\hline Source of variance & SQ & $\begin{array}{c}\text { Degrees of } \\
\text { freedom }\end{array}$ & $\begin{array}{c}\text { MQ } \\
\text { (Variances) }\end{array}$ & F \\
\hline Model systems & 0.0028373 & 6 & 0.000473 & 8.80 \\
Type of hydrocolloids & 0.0017274 & 2 & 0.000864 & 16.07 \\
Freezing process & 0.0009523 & 1 & 0.000952 & 17.71 \\
Error & 0.0017204 & 32 & 0.000054 & - \\
Total & 0.0072376 & 41 & - & - \\
\hline
\end{tabular}

$\mathrm{F}_{0.05}(6 / 32)=2.40$

$\mathrm{F}_{005}(2 / 32)=3.30$

$\mathrm{F}_{005}(1 / 32)=4.15$

In order to demonstrate the influence of model solutions compositions, type of hydrocolloids and freezing process on the rheological parameter (consistency coefficient) of the examined model systems, analysis of variance was executed (Table 8).

It was found that Fisher quotient value for all investigated sources of variation (composition of model solutions, type of hydrocolloids and freezing process) were higher than the theoretical value $(\mathrm{P} \leq 0.05)$ (Table 8$)$. Therefore, composition of model solution and kind of hydrocolloids as well as freezing process had statistically significant influence on consistency coefficient of the examined model systems.

\section{Conclusion}

Coefficient consistency and flow behavior index values of CMC solutions were determined by Ostwald-Reiner's power law.

Variance analysis showed that sources which were investigated (composition of model solutions, type of hydrocolloid and freezing process) had a significant effect on the consistency coefficient of all the model solutions subject to investigation.

The composition of solid matter rather than amount of solid matter had a greater effect on rheological parameters.

Model solutions prepared with ultrafiltered whey were greatly affected by the freezing process which in turn increased the coefficient consistency.

Due to the interaction of hydrocolloid and whey proteins or minerals, the viscosity of the model solutions prepared with ultrafiltrated whey dropped substantially. 


\section{References}

AlizADEHFARD, M. R. \& WiLeY, D. E. (1995): Viscosity of whey protein solutions. Iran J. Polym. Sci. Technol., 4, 126-133.

BHARGAVA, A. \& JELEN, P. (1995): Freezing of whey protein concentrate solutions and its effect on protein functionality indicators. Int. Dairy J., 5, 533-541.

BOYE, J. I., Alli, I., ISMAIL, A., GIBBS, B. F. \& KONISHI, Y. (1995): Factors affecting molecular characteristics of whey protein gelation. Int. Dairy J., 5, 337-353.

BOYE, J. I., ALLI, I., RAMASWAMY, H. \& RAGHAVAN, V. G. S. (1997): Interactive effects of factors affecting gelation of whey proteins. $J . F d S c i, 62,57-65$.

DZIEZAK, J. D. (1991): Hydrocolloids in food. Fd Technol., 45, 118-130.

GOFF, H. D., CALDWELL, K. B., STANLEY, W. \& MAURICE, T. J. (1993): The influence of polysaccharides on the glass transition in frozen sucrose solutions and ice cream. J. Dairy Sci., 76, 1268-1277.

HEGEDUŠIĆ, V. (1992): Advances in food process engineering, Faculty of Food Technology and Biotechnology, Zagreb, pp. 13-29.

HEGEDUŠIĆ, V., LOVRIĆ, T. \& PRLOG, M. (1991): Utjecaj hidrofilnih koloida na reološka svojstva modelnih otopina Šećera. (Influence of hydrocolloids on the rheological properties of model sugar solutions.) Kem. Ind., 40, 63-68.

HEGEDUŠIĆ, V., PILǏZTA, V. \& ŠUBARIĆ, D. (1994): Rheological and thermophysical properties of model ice cream mixtures. Preh. Biotehnol. Rev., 32, 67-71.

HEGEDUŠÍc, V., CARIĆ, M., HERCEG, Z. \& RADE, D. (1995): Rheological and thermophysical properties of dairy desserts before and after freezing. Mljekarstvo, 45, 191-203.

KER, Y. C. \& TOLEDO, R. T. (1992): Influence of shear treatments on consistency and gelling properties of whey protein isolate suspension. $J . F d S c i ., 57,82$.

KING, L. (1996): Whey protein concentrates as ingredients. Fd Technol. Europe, 3, 88-89.

KinSELLA, J. E. \& WhiteHEAD, D. M. (1989): Proteins in whey: chemical, physical and functional properties. Adv. Fd Nutr. Res., 33, 343-425.

PILŽ̌OTA, V., ŠUBARIĆ, D. \& LOVRIĆ, T. (1996): Rheological properties of CMC dispersions at low temperatures. Preh. Biotehnol. Rev., 34, 87-90.

ŠUBARIĆ, D., PILIŽOTA, V. \& LOVRIĆ, T. (1994): Rheological properties of some hydrocolloids mixtures at low temperatures. Preh. Biotehnol. Rev., 32, 71-76.

TRATNIK, LJ. (1998): Mlijeko - tehnologija, biokemija i mikrobiologija. (Milk-technology, biochemistry and microbiology.) Croatian milk society, Zagreb, pp. 345-380.

VAFIADIS, D. K. (1997): Delivering smooth sensations. Dairy Field, 180, 37-38.

XU, S. Y., STANLEY, D. W., GOFF, H. D., DAVIDSON, V. J. \& LEMAGUER, M. (1992): Hydrocolloid/milk gel formation and properties. $J$. Fd Sci., 57, 96-101. 